This item was submitted to Loughborough's Research Repository by the author.

Items in Figshare are protected by copyright, with all rights reserved, unless otherwise indicated.

\title{
Event and club volunteer potential: the case of women's rugby in England
}

PLEASE CITE THE PUBLISHED VERSION

http://dx.doi.org/10.1080/19406940.2015.1102756

\section{PUBLISHER}

(c) Taylor and Francis in affiliation with the European Association for Sport Management

\section{VERSION}

AM (Accepted Manuscript)

\section{PUBLISHER STATEMENT}

This work is made available according to the conditions of the Creative Commons Attribution-NonCommercialNoDerivatives 4.0 International (CC BY-NC-ND 4.0) licence. Full details of this licence are available at: https://creativecommons.org/licenses/by-nc-nd/4.0/

\section{LICENCE}

CC BY-NC-ND 4.0

\section{REPOSITORY RECORD}

Koutrou, Niki, and Paul M. Downward. 2019. "Event and Club Volunteer Potential: The Case of Women's Rugby in England". figshare. https://hdl.handle.net/2134/19209. 
Event and Club Volunteer Potential: The Case of Women's Rugby in England

Niki Koutrou* ${ }^{\mathrm{a}}$ and Paul Downward ${ }^{\mathrm{b}}$

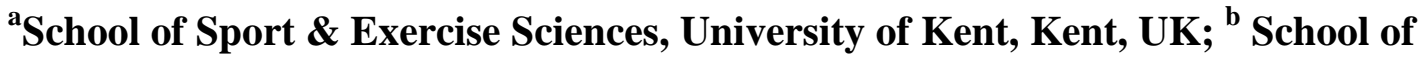
Sport, Health \& Exercise Sciences, Loughborough University, Leicestershire, UK

Abstract

Sports could not survive without volunteers as they are vital to the 'playing of sport'.

Volunteering in sports is typically associated with sports-club systems or sport events. The purpose of this study is to explore the potential of harnessing volunteer activity in different contexts, as a result of previous sports club volunteering experience and to establish what determines the decision to volunteer and to continue volunteering. This is important for government policy, given the current objectives to promote a 'Big Society' and reduce public expenditure. A total of 168 volunteers involved in women's rugby in England completed a web-based survey. Factor analysis was employed to summarise volunteers' satisfaction with their experience. The analysis yielded six reliable factors of volunteers' satisfaction. Regression analysis was then applied to identify which aspects of satisfaction, which motivations, how much previous sports engagement and which socio-demographic characteristics had an impact on actual volunteering for the women's rugby world cup, and future plans for volunteering in a rugby club at a rugby event, or at other sport events. Regression results provide statistical support for the transfer of volunteer efforts across activities. Thus, the UK government may meet its objectives to stimulate a Big Society and widen community engagement through sport volunteering, by acknowledging that social mobility varies between and within 
sports and is determined by the experiences, interests, motives and characteristics of both the individual volunteers and Voluntary Sport Organisations (VSOs).

Keywords: determinants of volunteer behaviour, single-sport event, sport clubs, Big Society. Social Capital

\section{Introduction}

Sports volunteering is vital to the 'playing of sport' (Taylor 2004), and is typically associated with either sports-club systems or single or multi-sport events (Schulz et al.2010). Sport volunteering in the UK generally accounts for $26 \%$ of the total volunteering activity. Voluntary sport clubs (VSCs) are where most of this volunteering takes place. For example, it is reported that VSCs account for $75 \%$ of sport volunteering and 83\% of sport volunteer hours in England. In contrast, major sports events comprise 1\% and 0.6\%, respectively (Sport England 2003). Despite this difference in relative size, however, sport events also need volunteers and are essential for elite-level sports as the culmination of competition within a given sport either in a single-sport event, organised by the governing body, or across a variety of sports in multi-sport events such as the Olympic Games that governing bodies seek to be involved in. Indeed, such interconnectedness in volunteering is recognised in UK sports policy in which it is argued that elite level-competition is essential for the symbiotic development of mass participation, for example, through Olympic legacy (DCMS/Strategy Unit 2002).

Prior to hosting the London 2012 Olympic and Paralympic Games, the formation of a Conservative-majority Coalition Government after the General Election in 2010 marked the promotion of the 'Big Society' idea. This was proposed in an attempt to use volunteering as a means of 'rolling back the state', to help in reducing the state 
deficit, following economic austerity, by decentralising state intervention and power from the government to the individual, and also to develop social capital through enhancing citizens' opportunities for a more active involvement in community life (Scott 2011). Investment into social capital accumulation was sought to be realised through non-traditional, informal educational methods, for example volunteering, given the benefits associated with such activities (Morgan 2013). One aspect of this was that it was proposed after the effective staging of the London 2012 Olympic Games, provision of sport participation opportunities through the voluntary sector was anticipated to lead the legacy objectives of the Coalition Government, to address the low sport participation rates and improve the health of the nation, and creating opportunities for individuals to volunteer to enhance their self-esteem, confidence and leadership skills; that is human capital which would be beneficial for the community as a whole (Paylor 2011). The Department of Culture, Media and Sport (DCMS), moreover, has also highlighted in their recent strategy for young people -'Creating a Sporting habit for life'- that sport volunteering has the potential to reinforce social capital development by retaining young people into sport once leaving school (DCMS 2012).

Despite such policy pronouncements, the evidence for a 'trickle down' effect is typically weak (Frawley and Cush 2011), with some research indicating positive effects from spectators attendance at events (Ramchandani and Coleman 2012) as an inspiration to participate. It remains, however, that volunteers are important for both events to occur and to facilitate mass participation. It follows that the recruitment, training and organisation of volunteers should be informed by the interconnections between club and event activity. This is particularly important because the recruitment of new volunteers is five times more time-consuming than retaining the 
existing ones (Strigas and Jackson 2003). In essence, this is also reinforced by the very nature of sport and sport clubs where social inequalities often exist and social capital acquisition vary between and within sports (Coalter 2007). For instance, individuals who come from a higher socio-economic status and well networked community are more likely to maintain their involvement, develop and mobilise social capital in different sporting opportunities compared to individuals from less advantaged communities (Kisby 2010, Taylor et al. 2012).

As discussed in the next section, the sport volunteering literature largely focuses on volunteers' motivations, satisfaction and future volunteering, or the substantial economic contribution of volunteers in a wide array of activities pertaining to either sport events or sports clubs (Clary et al. 1998, Cnaan and Goldberg-Glenn 1991). There is some literature that examines the impact of sports event volunteering on future volunteering (Downward and Ralston 2006, Doherty 2009, Hallmann and Harms 2012). It follows that little is known about how specific sports' club volunteering provides a platform from which to harness volunteer effort in sports events in the same sport, or in different sports to contribute towards society's broader sporting needs. In particular, in order to implement government policies of increasing community engagement through volunteering, more evidence is needed on the different motives, values and interests that attract individuals to volunteer and on the factors that promote future volunteering in sports. Consequently, this article, building upon previous work from Taylor et al. (2012), aims to address three key concerns in the literature. First, to identify the separate effects of different factors, such as socio-demographic characteristics, previous engagement in sport, motivations and satisfaction with volunteering on the decisions to continue volunteering. Second, to examine whether involvement with one sport volunteering 
context, for example, in sport clubs, stimulates interest in further volunteering in similar or different sport volunteering contexts, such as in sport events. Lastly, to comment on the actions that should be undertaken from the government and national governing bodies (NGBs) to ensure that the 'Big Society' policy could be realised through volunteering in sports.

This article begins to fill this gap in the literature, by examining a case-study of women's rugby union in England. It was conducted with the support of the Rugby Football Union for Women (RFUW). The RFUW is the national governing body for the sport of women's rugby in England and aims to promote, develop and govern both community and elite women's rugby in England. It was founded in 1994 and at the time of this research consists of 288 clubs comprising of 187 senior clubs, 54 student teams, 110 Under 18's teams and 125 Under 15’s teams (RFUW, 2010). As the RFUW hosted the Women's Rugby World Cup in August 2010, this presented an ideal opportunity to test the actual impact of club volunteering on event volunteering as well as to investigate stated intentions of future activity in volunteering through regression analysis. The RFUW aimed to recruit volunteers from both clubs and the community.

\section{Literature Review}

It is argued that one of the positive externalities derived from volunteering in sports is that it contributes to social capital development and social mobility (Handy and Brudney 2007). Social capital refers to the 'trust and reciprocity' occurring on individuals' relationships when working together for achieving a common goal (Bailey et al. 2003). Bourdieu (1986) defined social capital as 'the aggregate of the actual or potential resources which are linked to the possession of a durable network 
of more or less institutionalised relationships of mutual acquaintance and recognition' (p.248). In this regard, the role of sports and sport clubs in promoting social capital and a shared identity is commented on a number of sources (Coalter 2007, Delaney and Keaney 2005). Similarly, volunteers are often described as the targeted 'soft infrastructure' following the legacy plans of governments aiming to host a major sport event, referring to the potential of mobilising human resources to other similar events and projects that the wider community would benefit from (Solberg and Preuss 2007).

As noted, the role of volunteering in embracing wider communities is especially critical nowadays, as recent policy priorities of the previous Coalition Government in the UK acknowledge the value of the voluntary sector as an asset in empowering social action and a more dynamic and active community engagement, development and responsibility (McCabe 2010). The 'Big Society’ policy in the UK emerged in 2010 after the British Elections, when the Conservatives formed a coalition government with the Liberal-Democrats, with the aim 'to put more power and opportunity into people’s hands' across neighbourhoods, communities, social enterprises, charities, clubs and local authorities (Cabinet Office 2010, p. 1). The economic austerity climate and the necessity for reduced public expenditure led to the re-examination of the relationship between the state and the society in the delivery of public services, by bringing local communities and citizens to the fore of improving society through volunteering (Smith 2010). While, the boundaries of the Big Society policy are not restricted to sports volunteering, it should be acknowledged that the main area that volunteering takes place in the UK is sports (Taylor et al. 2012). Therefore, sport volunteering is expected to play a great role in Big Society policy aspirations, as a substitute for the provision of reduced public 
sector opportunities and as a means of promoting community activism (HM Government 2010). However, there is considerable debate over whether the Big Society Policy is simply just a means to an end, implying that the policy is used to legitimise the cuts to public expenditures and the shrinking over public services (Pattie and Johnston 2011). Critics of the Big Society policy question its potential to bring more people into volunteering, as a result and as a substitute of reduced government interventions. The assumption that active community engagement enhances the acquisition of social capital and subsequently facilitates social mobility is rather unexplored (Morgan 2013). In addition, another concern with the Big Society policy is its focus on enhancing volunteer activity in the most deprived communities and areas of the country. However, as several authors argue the decision to volunteer depends more strongly on macro-economic factors and the magnitude of social and relational networks than on the place of residence. For instance, the socio-economic status of an individual and his mutual acquaintances will have an impact on their decisions to form social networks and volunteer (Kisby 2010, Taylor et al. 2012). In addition, individuals, organisations or communities with a higher network of connections are more likely to mobilise social capital through engaging in multiple activities and if such network construction is allowed by the time, effort given and other resources at their disposal (Bourdieu 1986, Morgan 2013). This suggests that current inequalities in sport volunteering will continue to exist, if no additional support is provided by the government to tackle them (Kisby 2010, Taylor et al. 2012). There is also lack of empirical evidence to support whether this bottom-up approach to policy implementation coincides with the values, willingness, ability and interest of the grass-roots organisations to be involved in the process of promoting and providing sport participation opportunities 
and facilitate social mobility through social capital development (May et al. 2013). Voluntary sport clubs (VSCs) are more restricted to outsiders and tend to operate in isolation compared to other voluntary associations, given that their members' interests are concentrated around specific activities and stem from the love of sport. Thus, VSCs do not reflect general volunteers' motivations for involvement in a broader sense suggesting that opportunities for social capital development are occasionally neglected in sports (Morgan 2013, Nicholson and Hoye 2008). Given that British volunteers are more likely to get involved in sport clubs for the love of the sport, or to give something back to the club (Allison 2001), rather than to achieve the Government's policy aspirations, it is doubtful whether the individual sport volunteer will be engaged in the 'Big Society' mission for social capital creation (Morgan 2013). However, it should be noted that while volunteering in sport clubs reflects the needs of like-minded people and the club's priorities, individuals who engage in club volunteering bring into the network, pre-existing levels of social capital developed through their involvement in similar pursuits and this potentially reinforces social mobility (Nicholson and Hoye 2008). This aligns to Putnam's (2000) distinction of social capital creation through bonding, bridging or linking processes referring to the way connections and networks are formed in sports between homogenous or rather disparate groups of people.

Thus, the findings of the current study will inform policy makers on whether the aspirations of a sport participation, physical activity and volunteering legacy, after the London 2012 Games can be translated into wider community involvement and social action through sport volunteering, and whether there is potential for VSOs and individual volunteers, to be transformed into active agents of the 'Big Society’ idea. 
To generate the hypotheses to be investigated, and to provide a rationale for the factors to be included in this empirical research, the volunteering literature is now reviewed. Examination of the VSC and sports-event volunteering literature reveals relatively distinct sets of motivations for volunteering and constituencies from which volunteers emerge. These are now discussed along with the possibility that volunteers' satisfaction with their activity and sports engagement may then lead the individual to progress to other volunteering pursuits in organisations or at events.

\subsection{Volunteer motivations}

An extremely large and international literature has generally argued that the motivation to volunteer arises out of a balance between self-interest (albeit expressed in a variety of ways) and altruism (see Stebbins 1996, Taylor 2004). For example, early work such as Clark and Wilson (1961) identified that there are both tangible and intangible dimensions of volunteering. These stem from the material reward from being engaged in an activity or the solidarity and emotional attachments that are experienced, respectively. Such motivations have been formalised into scales such as the Motivation to Volunteer (MTV) scale developed by Cnaan and Goldberg-Glen (1991) in which both altruistic and egoistic motivations for volunteering are identified. More recently, the Volunteer Function Inventory (VFI) derived from Clary et al. (1998) identifies six motives ranging from altruism, development of skills, social interaction, career enhancement, personal esteem and personal development.

Despite this formality of conceptualisation and direct applications of these scales in empirical work, the motivations for volunteering are also expressed more informally in a variety of empirical contexts. For example, altruism, through helping the 
organisation to achieve its goals by putting personal efforts and time commitment into sport, is noted in sports clubs in general in England (Sport England 2003). This particularly happens with the former players of clubs, as it is reported that they have an existing interest and desire to repay the organisation from which they benefited in the past in the sector they volunteer for (Cuskelly et al. 2006; DCMS 2011). Moreover, it is noted that most sport volunteers start to volunteer in order to support a cause they believe in, or because they want to support a member of their family that participates in the club's activities, such as their children (Doherty 2005). Of course, there are social benefits too, in which degrees of self-interest emerge. Consequently, seeking friendship and camaraderie through club membership are significant motives as well (Sport, England 2003, Doherty 2005, Cuskelly et al. 2006).

In the context of sports events, investigations of motivations have also produced formalised scales, with subsequent application to specific contexts. Farrell, Johnston and Twynam (1998) proposed the Special Event Volunteer Motivation Scale (SEVMS) based on a development of the VFI. This measures four underlying dimensions covering the desire to contribute to community by doing something useful; social interaction and networking; extrinsic influences on an individual's propensity to volunteer; and, finally, the expectations of others. Bang and Chelladurai (2003) proposed the Volunteer Motivations Scale for International Sporting Events (VMS-ISE) and identified the importance of; expressing values; patriotism; interpersonal contacts through meeting new people; personal growth through feeling needed; career orientation through gaining experience and, finally, extrinsic rewards connected with factors such as access to the event. Subsequently, 
Bang et al. (2008) have added the love of sports as a general motivation for such volunteering.

An important feature of the literature on volunteering motivations is the possibility that motivations may change over time and across settings (Slaughter 2002). For instance, it is argued that long-term volunteers are more likely to volunteer in order to give something back to the community rather than to experience being part of a unique experience, or the seeking of social interaction and networking (Cuskelly et al. 2006). The latter reasons might be much more likely at a sports event given its relatively unique nature. Thus, as Cuskelly et al. (2006) identified, experiences may influence volunteers' levels of commitment to an organisation or a voluntary cause. It is argued that this issue needs to be considered more closely by researchers, in order to evaluate the impact of such changes in time and context on future volunteering behaviour (Bang et al. 2009). The next sections, consequently, indicate how the context of volunteers, through their socio-economic circumstances as well as their more general engagement in sports, in addition to their experiences, affects volunteering.

\subsection{Socio-Demographic Characteristics}

The empirical research reveals that VSCs and sports events tend to recruit volunteers from quite distinct socio-economic constituencies that are, in turn, different from other volunteer contexts. Sport England (2003) and more recently the DCMS (2011) reported that compared with general volunteers, sport-club volunteers tend to be from higher socio-economic groupings, possess a higher education level and, typically, have a White-British ethnic background. Moreover, parental motivation for committing to volunteering is less relevant in the sporting context than elsewhere. It 
is argued that in part this is because males are more likely to volunteer than females and younger age-groups are more prevalent (DCMS 2011). Most sports volunteers are in the relatively low age band of 35-44 years (Nichols and Padmore 2005). On the other hand, it is argued that where present, older volunteers are more likely to undertake formal roles in clubs (Sport England 2003). Major-event volunteers' characteristics can reflect the gender and age profile of the participants in the specific sport concerned, producing similar profiles to club volunteers. However, it is also noted that the larger and more unique the event the broader the volunteer demographic. There can also be much less connection with sports (Downward and Ralston 2006).

\subsection{Sports Engagement}

The fact that major-event volunteers can be less connected with their sports is indicative of the possibility that prior sport engagement, for example, as a participant, might be an important factor that underpins the motivation for sports volunteering. However, the role of sports engagement has not been researched well in the volunteering literature. Many studies, such as those reviewed in the motivation literature in section 2.1, do not investigate its relevance at all, or subsume its impact within generalised concepts such as the love of sports, or retaining links with clubs. Burgham and Downward (2005), however, identified a strong influence of volunteers' previous participation in swimming, as well as the current participation of their children, in determining the decision to volunteer and the duration of the activity. Finally, based on small-scale qualitative research, Cuskelly and O’Brien (2012) identified that the psychological and social connection of the former players can underpin the transition to become a volunteer. 


\subsection{Satisfaction with the Volunteering Experience}

The final determinant to be considered concerns how satisfaction through experience of volunteering may affect continued activity in the future, and its potential transfer to other contexts. The literature argues that volunteers' job satisfaction is an outcome of their experiences (Cuskelly et al. 2006), which is essential in leading to higher levels of commitment to the sports organisation and then consistency in subsequent behaviour (Stebbins 1996).

In this regard, research into community organisations suggests that if individuals experience fewer rewards than costs from their volunteer involvement with an organisation, then this relationship is not likely to be maintained and volunteers may withdraw from their duties (Galindo-Kuhn and Guzley 2002). For example, Silverberg et al. (2001) concluded that job satisfaction of volunteers at public recreation parks arises from a combination of the job environment and psychological needs that are met by volunteering. Therefore, volunteers expect appreciation, support, sound operations, good communications with co-workers and meeting their personal aspirations, in exchange for their time and efforts currently and in the future. Most recently, Schlesinger et al. (2012) identified that the solidarity experienced through volunteering, along with job satisfaction correlated positively with long-term volunteering commitment.

Similar sentiments are expressed at sports events. Downward and Ralston (2006) identified that experiences at the Manchester Commonwealth Games encouraged volunteers' greater interest in sports, as well as their intentions to volunteer in future sports and non-sports contexts. Similarly, Doherty (2009) identified that experiences at the 2001 Canada Summer Games affected the future intentions of volunteers to be 
involved in another major festival or event in local communities. Doherty (2009) also noted that the study would be improved by accounting for the influence of volunteers' socio-demographic characteristics on their stated future behaviour, as these were not investigated.

\section{Theoretical Foundations}

The above discussions are indicative of a well-established literature that examines the determinants of broadly either VSC or sports-event volunteering. They suggest that the motivations of volunteers, and their related underpinnings deriving from volunteers' socio-economic background and their engagement with sports, as well as satisfaction with their experience, help to determine volunteer effort. To a greater or lesser extent, the discussion of each of these determinants also indicates how they can affect future volunteering. For example, through the desire to experience unique events, or to retain community connections, that volunteering is highly contingent on socio-demographic characteristics, and can be affected by sports participation. However, it is only in a small number of studies in the event-volunteering literature that a direct examination of the transfer of volunteer effort to other contexts has been undertaken. For example, Hallmann and Harms (2012) identified that the motivations to volunteer at a handball or equestrian event were positively associated with intentions for future sports club or sports event volunteering. Furthermore, by the authors' own admission, the model did not account for the satisfaction of volunteers and was thus incomplete.

A number of specific theoretical approaches have been adopted to construct and to interpret the evidence on why people volunteer and how and why volunteer behaviour changes. However, there is no consensus, or uniformly acceptable 
approach. In part, this reflects the multidimensional nature of volunteering, but it also reflects the different theoretical traditions connected with different disciplines (Hustinx et al. 2010). Consequently, an economics approach might focus on volunteering as the rational balancing of the costs and benefits of altruistic behaviour, and examine volunteering as the consumption-production of 'club-goods' with the consequent development of human and social capital. Prior investment in human and social capital might then make it more 'economical' for an individual to volunteer more as it contributes to their sense of individual well-being. The point about club-goods is that their consumption-production enhances individual wellbeing which may be directly influenced by enhancement in the well-being of others. Self-interest is not the same as selfishness (Downward et al. 2009).

Sociologists, psychologists and political scientists emphasise that it is primarily social cohesion, personality traits such as pro-social behaviour, or civic engagement and formation of social capital that drive volunteering (Hustinx et al. 2010). Accounting for changes in volunteering behaviour might then draw upon socialexchange theory. This suggests that the organisation and the volunteer are tied to an exchange relationship with the needs of both being met in order for this relationship to be maintained (Doherty 2005). Alternatively, following a process called disconfirmation (Oliver 1980), and similar to consumers who continue to purchase products or services when they are satisfied from what they experienced, volunteers may continue to volunteer depending on the extent that their volunteering experience is satisfying, rewarding and meets their needs (Cnaan and Goldberg-Glen 1991).

In the current research, and recognising the multifaceted nature of volunteering, no specific theory is prioritised or sets of theories tested between. Rather, to facilitate 
the empirical analysis, and following the approach of Downward and Ralston (2006), the current research embraces the shared predictions from these theoretical perspectives as hypotheses to be investigated.

Consequently, it is expected that the motivations for, and satisfaction with, volunteering from VSC volunteers will not only contribute to further sports club volunteering intentions, but also transfer to volunteering at the same sports' events, as well as those of other sports. It is also to be expected that such behaviour will be influenced by engagement with sport and socio-economic circumstances.

Whilst these hypotheses take their foundation from either the VSC or event contexts, it applies them to examining not only future club volunteering, but also the transfer of effort between VSC and event volunteering. Some suggestions for the mechanisms by which this happens can be offered. First, common to the different theoretical traditions noted above is the shared perspective that volunteering can increase social capital. The different theoretical perspectives on the specific role of sports and sports clubs in promoting social capital are reviewed in a number of sources (Delaney and Keaney 2005, Coalter 2007, Downward and Rasciute 2012). Nonetheless, as indicated earlier, drawing on Putnam (2000), the literature generally recognises that both bonding and bridging social capital can be developed through voluntary association. The former applies to the strengthening of links between members of homogenous groups, whilst the latter to the development of links across more heterogeneous groups. Recognising this distinction suggests that it might be expected that volunteers who have formed tight-knit communities in clubs, through their joint experiences, might be less inclined to volunteer in a different context, such as an event, even though it may be connected with the same sport if bonding dominates. If it does not, then bridging might be encouraged which would promote a 
transfer of effort across contexts. The balance of these forces needs to be identified empirically. Second, the motivations to volunteer, as discussed earlier in the specific context of events or VSCs, draw upon deeper more abstract desires to satisfy selfinterest, but also to express altruistic behaviour. It follows, therefore, that the volunteer will seek to express concrete expression of these motivations in a variety of different contexts. It might be the case that a volunteer is prepared to transfer his efforts to another context, even if the current experience has not been satisfactory in seeking to meet the needs expressed by the motivations. This implies that volunteers might substitute their efforts. This nuance represents an additional element to the standard hypothesis of the literature and comprises further theoretical novelty in the current research.

\section{Context, Data and Variables}

\subsection{Population, Sampling and Data Collection}

The population of women's rugby club volunteers is to a degree uncertain. Consistent with the developing profile of women's rugby, women's teams are often based at traditionally male clubs and share training facilities and coaches. They have merged or move their base between clubs and cover much wider areas of recruitment of players and competition (RFUW 2010). The founding of the national governing body of the women's game, the RFUW in 1983, is a prominent example of groups of like-minded individuals, who formed their own organisational structures to enable previously excluded social groups to participate in their sport of interest (Houlihan and White 2002). Rugby is a traditionally male prevalent sport (Dunning and Sheard 1979), and despite that men's rugby had its own governing body, the Rugby Football Union (RFU) since 1871, the women's game was developed much later by a group 
of women graduates, who had practised the sport while at University and sought to continue playing rugby after graduating (Houlihan and White 2002). Thus, it might be expected that women's rugby in England attracts participants and/or volunteers of a higher educational background, given that University teams established the sport. This supports Coalter (2007) in arguing that social capital manifestations may vary between and within sports.

Club volunteers may also share duties with the men's game, which is allowed for in the analysis. Consequently, the specific club identities of volunteers were not a focus of the research. Nonetheless, as records suggest that most women's rugby clubs are run with help from no more than five specifically identified formal volunteers (RFUW 2010), this suggested a base population of approximately 750 volunteers as a total of 150 clubs were identified as taking part in the national league structure of women's rugby at the time of the survey. Nonetheless, as only 100 clubs had an active online page at the time of the survey, this constrained the sampling frame to the corresponding potential 500 club volunteers.

An email invitation including a link to an internet-administered questionnaire was sent to each of the contact addresses for the club encouraging them to identify respondents. The research instrument was examined by a panel of experts, including academics and RFUW representatives, prior to distribution, to ensure content validity and any ethical implications. Access to the volunteer database of the RFUW was not granted to the researchers, however, it was agreed that a link to the online questionnaire would be sent by email to the relevant volunteers, by the RFUW volunteer coordinator. A participant information sheet was also included to inform potential respondents that their participation is voluntary, and all personal information provided would be treated with absolute confidentiality by the 
researchers. The sampling yielded a total of 168 responses. Incompletion of some items suggested that for most variables, 161 responses were usable. In the regression analysis, the available sample was 131 responses, which comprised the maximum set of observations across all of the variables analysed. This is, in absolute sense, a small sample. Rules of thumb for regression analysis, for example, often suggest that a ratio of five observations to one variable is required (Hair et al. 2006). As is discussed below, 33 covariates are used to measure motivation, socio-economic characteristics, sports engagement and satisfaction with volunteering which suggests a required minimum sample size of 165 . However, it can be shown that for a multiple regression, based on a widely accepted level of the power of a test of 0.8 , a significance level of $5 \%$, the 33 covariates to be employed in the study, and a conventionally 'large' effect size of 0.35 , a minimum sample size is 100 observations (Cohen 1988). Given also that the population of volunteers is small and the response rate for the current study represented more than a third of this, the sample was deemed satisfactory for empirical analysis. The survey instrument was distributed prior to the rugby world cup and then, following an audit of respondents and actual event volunteers' contact details, as provided by the RFUW, it was possible to identify those that actually volunteered at the rugby world cup.

\subsection{Dependent Variables}

Table 1 provides details of the dependent variables. All of the variables except actual volunteering at the rugby world cup, 'rwc', were scored on a seven-point Likert scale with values ranging from ' 1 - strongly disagree' to '7- strongly agree'. The variable 'rwc' was a binary variable with ' 1 - volunteered' and ' 0 - did not volunteer' as values. 


\section{INSERT TABLE 1 HERE}

The statements that were used to investigate volunteers' future intentions were adapted from Downward and Ralston (2006), who sought to explore the future intentions of 2002 Manchester Commonwealth Games volunteers as a result of experiences at the event. The table reveals that recognising that the mean value of a binary variable represents a sample proportion, approximately $24 \%$ of the club volunteers also volunteered at the rugby world club. Significantly, there is also support for further volunteering intentions, but this tends to prioritise club activity, as indicated by a higher mean value and smaller standard deviation than is the case with future volunteering at rugby events and other sports events.

\subsection{Independent Variables}

Table 2 provides details of the socio-demographic variables used in the analysis. As the variables are all measured as binary values, the mean values indicate the sample proportions of the relevant categories being measured. The data reveal that the sample is effectively balanced between males and females, suggesting that the support for women's rugby is not highly gendered, and that only approximately $27 \%$ of the sample have dependent children.

\section{INSERT TABLE 2 HERE}

As the age categories reveal relatively balanced proportions between 25 and 60 years of age, this suggests that there are, perhaps, fewer connections with children as a form of association with women's rugby than in other sports. Here, as Nichols (2006), through secondary analysis of Sport England 2002 data, identified that 51\% of all sport volunteers initially volunteered because their children took part in sport. It is revealing to note that out of the $27 \%$ of volunteers with children, $21 \%$ of this 
total comes from; $12.4 \%$ belonging to the age range of $35-44$ years, and $8.7 \%$ belonging to the age range between 45 and 59 years. The data also show an extremely high incidence of degree-level education. As one might expect a younger age profile of volunteers if their children are involved in the sport, the wider age profile suggests either that older volunteers in women's rugby are perhaps less constrained by family commitments, or that they might have had children later in life. This could also be reflected in the higher educational profile of volunteers. Higher education has also been instrumental in facilitating the development of women's rugby as noted earlier. Reflective of the broader population (Sport England, 2003, DCMS 2011), however, approximately 92\% of the sample is White British.

Table 3 provides descriptive information on the sports engagement of volunteers in a number of binary and continuous variables, as well as volunteer motivations for being involved in their rugby club. In the latter case motivations were measured by a series of questions that were adapted from Sport England (2003), which was the last major investigation into sports volunteering in England. Each of these variables was measured on a 5-point Likert scale.

\section{INSERT TABLE 3 HERE}

The first sets of variables reveal a high degree of sports engagement generally, but particularly with rugby. Almost $60 \%$ of the sample currently played the game, with approximately $67 \%$ of the sample primarily volunteering in the women's game but, nonetheless, indicating the joint efforts with the men's game as noted above. As is typical with years of experience, and hours volunteered, the data suggest skewed distributions, but it is clear that a high level of volunteer commitment is evident both 
during and outside the rugby season. Significantly, approximately $44 \%$ of the sample played other sports and approximately 32\% of volunteers also volunteered in other contexts. These latter results hint at the potential for the transfer of volunteer effort across contexts. The motivational variables provide further supporting evidence of the sentiments expressed in the literature review. Ranked most highly are motivations concerned with some self-interest, that is meeting the individual's needs, but, it is noted that this is in the context of also wanting to help people, to meet the needs of family and friends and the community. Much less relevant motivations are connected with starting the club - which is potentially salient in the developing sport of women’s rugby - or undertaking activities connected to their paid work.

Finally, table 4 presents the items that were used to construct the independent variables measuring satisfaction from a factor analysis as presented in the next section. The items were adapted from Silverberg et al. (2001) who aimed to measure the level of job satisfaction for volunteers in public recreation parks. Some items were removed from the original scale or slightly modified, in order to be suitable for use with the rugby volunteers' sample. The rest of the items reflected the benefits associated with the sport volunteering experience, for example, as identified in Sport England (2003). All of the questions were rated on a seven point Likert scale from 1 (strongly disagree) to 7 (strongly agree).

\section{INSERT TABLE 4 HERE}

Mean scores are typically above four, and close to five or six with standard deviations less than two, and often close to one. This suggests broad satisfaction with experiences. There are some nuances apparent in the data. The first is that lower means scores around three or four are typically accompanied by higher standard 
deviations, indicating less uniformity in satisfaction. The second is that it is the items measuring negative experiences that typically fall into this category. This suggests that there is a distinct subset of volunteers that have experienced lower satisfaction than others. This hints at the potential relevance of dissatisfaction with volunteering experiences on the transfer of effort. The higher means scores above five appear to be broadly connected with satisfaction from the role undertaken in contributing to the community, mean scores around four are typically connected with good relationships within the club, and lower scores associated with job tasks and lack of communication in, and appreciation from, the club.

Finally, an exploratory factor analysis was undertaken to summarise the items measuring satisfaction from volunteering. Factors were extracted by making use of a Principal component analysis with Varimax rotation.

An examination of the Kaiser-Meyer Olkin (KMO) measure of sampling adequacy suggested that the data matrix was amenable to factor analysis $(\mathrm{KMO}=0.861)$ and the Bartlett test for sphericity indicated that the dataset was significant at the 0.000 level. Items that loaded higher than 0.45 on a single factor were retained in keeping with the literature (Stevens 1996, Hair et al. 2006). Initially eight factors were extracted by considering their eigenvalues being greater than 1.0, as well as the percentage of the total variance explained by each factor. However, the other factors comprised only two items, or had low reliability and these were eliminated from further analysis (Stevens 1996). The subsequent factor analysis produced five factors accounting for $67.2 \%$ of the variance in the data. 


\section{Results}

\subsection{Factor Analysis}

Table 5 presents the results from the exploratory factor analysis.

\section{INSERT TABLE 5 HERE}

The five extracted factors were labelled: satisfaction with the volunteer role and contribution (rolesatisf), satisfaction with contingent rewards (rewards1), satisfaction with communications (communication), satisfaction with club’s support (support), and satisfaction with volunteer appreciation (rewards2). Significantly, the communication and rewards2 factors measure elements of dissatisfaction connected with club organisation and communications and the lack of reward for volunteers.

The Cronbach Alpha reliabilities for each of the extracted factors ranged from 0.66 to 0.94 . As the current study follows an exploratory research framework, in keeping with the literature, a Cronbach's Alpha value of 0.60 was adopted as acceptable (Hair et al. 2006, Suhr and Shay, 2009). The findings demonstrate that the implemented satisfaction scale was a reliable instrument.

\subsection{Regression Analysis:}

In this section, results of the regression analysis are presented. The regressions examine the impact of the club volunteer's satisfaction with, and motivation for, volunteering, their engagement with sports, and the volunteer's socio-demographic characteristics upon the decision to volunteer for the women's rugby world cup, and intentions to volunteer further for rugby events, the rugby club and other sports events.

INSERT TABLE 6 
Table 6 provides the regression results for each case. The dependent variables are given at the top of the relevant column. As 'rwc' is a binary variable, a logistic regression was employed. In the other cases of Likert scales, ordinary least squares (OLS) regression was employed. For each model, the table presents estimated coefficients and the corresponding (asymptotic) ' $\mathrm{z}$ ' or ' $\mathrm{t}$ ' values. The latter are all calculated using robust standard errors to control for potential problems of heteroscedasticity. This might arise because of the use of cross-section data and that measurement of the dependent variables takes place on truncated scales. The table also details the sample sizes as ‘ $n$ '. The 'pseudo' $\mathrm{R}^{2}$ along with the corresponding Wald test statistic, which tests the null hypothesis that the 'pseudo' $\mathrm{R}^{2}$ is equal to zero, are also presented for the logistic regression. The corresponding $\mathrm{R}^{2}$ and $\mathrm{F}$ statistic for the OLS regressions are also presented. For ease of interpretation, significant variables at the $1 \%, 5 \%$ and $10 \%$ level are reported and are indicated by '***', '**' and '*', respectively. In the case of the logistic regression, for 'rwc', marginal effects are presented for significant variables, to indicate the scale of effects; that is the probability of volunteering for the rugby world cup, for a given unit change in the independent variable concerned. All Variance Inflation Factor (VIF) statistics were below 10 with the vast majority of variables less than 2, which is indicative of no serious multicollinearity in the results. Nonetheless the oldest age-group was dropped in the estimation because of no variation in the data and consequent collinearity with the constant. The fact that this occurs for the oldest age groups is to be expected.

The results of the regression analysis support the hypotheses under investigation. This can be illustrated by examining each equation in turn. For 'rwc', the analysis suggests that for the satisfaction with volunteering variables, satisfaction with the volunteer role and communications within clubs raises the likelihood of the club volunteers having volunteered for the women's rugby world cup. As noted earlier, the job environment, communication with co-workers, and a volunteer role that meets volunteers' needs are strong determinants of 
volunteer commitment (Silverberg et al. 2001, Schlesinger et al. 2012), which is evident in this volunteering context as well.

For the sports engagement variables, currently playing rugby enhances the chance of volunteering for the rugby world cup. However, this is not the case for years volunteering. This perhaps indicates the relative uniqueness of the rugby world cup as well as the opportunity costs of time. This is also suggested in the motivation variables in which as well as looking to meet others' needs, which captures the usual altruism of volunteering (Clark and Wilson 1961, Cnaan and Goldberg-Glen 1991; Sport England 2003), having time to spare increases the probabilities of volunteering at the event. The socio-economic variables confirm data from the Active People Survey (APS) 1 (2005/2006) and the 2002 Sport England survey that suggest the positive effects of ethnicity and the level of education on expected sport volunteering (Taylor et al. 2012), as white British are more likely to volunteer in sport and for the world cup, as with respondents having a higher education. Significantly, working full-time and being a student are factors that reduce the probability of having volunteered for the world cup. This suggests that both time and income might have constrained opportunities to volunteer in this context, confirming previous research that suggests income, time constraints and the level of engagement in sports volunteering are directly related (Taylor et al. 2012). As, APS 1 offers contradictory findings by suggesting that generally students and adults in paid employment are most likely to volunteer in sport (Sport England 2009), this contrast is perhaps linked to the uniqueness of the event.

The OLS results for 'othrugevt' show that for the satisfaction variables, communication within the club would promote a greater intention to volunteer for another rugby event. None of the sports engagement variables are significant. For the motivation variables, and consistent with the literature, for example as stated in Sport England's 2002 survey, significant determinants are connected with the personal objectives of seeking to make 
friends but also altruism by offering to help, and then in meeting the needs of current friends and family. Being of white ethnicity and retired are the main socio-economic variables increasing the stated intention to volunteer at another rugby event. Interestingly, the APS 1 supports that the economically inactive are less likely to volunteer (Sport England 2009).

The regression results examining future intentions to continue volunteering in the club, 'rugbyclbvol', show that satisfaction with the roles undertaken is significant for the satisfaction variables. For the motivation variables, there is evidence of self-interest in that having the personal needs of the volunteer being met by the volunteer experience reduces the intention of further volunteering in the club. This is because volunteers are also more likely to express an intention to increase their volunteering in the future as a result of seeking to make friends rather than to help others, which would logically include their current friends. Being of white ethnicity is the only socio-economic variable that is significant and in support of past research that identifies that white British are more likely to volunteer in sports in the UK (Sport England, 2003, DCMS 2011).

The final regression results examine the intention to volunteer for other sport events, measured as 'othspevt'. The satisfaction variables that are significant include satisfaction with current roles and with communication within the clubs. None of the sports engagement variables are significant. As with 'othrugevt', having a motivation to meet the needs of others in the family is shown to reduce the stated intention. However, this does not mean that an altruistic motivation is missing, as seeking to help others is, in contrast, a positive impact on intentions to volunteer. As with the other cases, having a white British ethnicity increases the stated intentions to volunteer for another sports event, other than rugby, but there is also evidence of age effects unlike in the other regressions. 
Overall, therefore, there is evidence that both the retention of club-volunteering effort, as well as its transfer to other contexts is affected by volunteer satisfaction as experienced through the club. There is also evidence of altruistic motivations, in seeking to help others, and not necessarily family members or pre-existing friends. Sports engagement and the socioeconomic context also affect the results, but less generally. Collectively these results suggest statistical support for the hypothesised impact of standard variables affecting volunteering to the transfer of volunteer effort as stated earlier.

It is also apparent, however, that there are some variations in the emphasis of the results. For example, sports engagement was only significant for actual volunteering at the rugby world cup, reflecting the significance of self-interest such as love of the sport and being a current or former athlete in determining the transition to become a volunteer (Burgham and Downward 2005, Cuskelly and O’Brien 2012).

It was also only evident here that previous volunteering experience was less likely to promote (world-cup) volunteering and that the motivation of 'having time' was more likely to do so, as was meeting the needs of existing friends and family. This could be due to women's rugby being of a developing stage, which perhaps suggests a greater reliance on the existing tightknit and informal structures within the clubs to support the sport, compared with other sports that may rely on paid employees. Overall, this suggests that the volunteering activity associated with this major international sports event for women's rugby, compared to the other contexts, had a degree of greater spontaneity and uniqueness associated with it and primarily draws upon existing club connections. The former might also explain why the income and time constraints associated with working full-time and being a student also both had a negative influence on actual volunteering at the event, but not in the other contexts, which is consistent with previous research suggesting that students and paid employees are overrepresented in sport volunteering (Sport England 2009). 
In contrast, in the analysis of other rugby events, which is most likely to include local and regional tournaments, older retired volunteers were more likely to express an intention for further volunteering. The significant motivations were also to make friends rather than to help current family. Making friends also appears to be one of the main motivations for further intended club volunteering, and this suggests that a degree of self-interest is predominant. This is because if club volunteering meets volunteer needs, they are less likely to continue volunteering in the future. This reduced intention is also the case in connection with the motivation of seeking to help others. These results suggest that with club volunteering, a degree of satiation of future intended activity can occur, once the need to make friends are met and is consistent with McClelland's (1961) motivational theory that supports the need for affiliation as a relevant motivation in explaining volunteers' behaviour.

Finally, it is only with the results for other sports events that significant age effects are identified. They indicate that intentions to volunteer for other sports events are most likely for the younger to middle-aged groups. As no age effects are significant in the rugby volunteering equations, this suggests that variations in age have no obvious effect on volunteer behaviour within the sport, but transferring volunteering activity to other sports could be age limited. This could of course, reflect a reluctance of older volunteers to move across contexts, and is perhaps linked to the commitments that older volunteers typically have in their sport, as they tend to undertake more formal and supervisory roles within the club and their motivations prioritise the desire to give something back to the club, and the need for affiliation by establishing or maintaining interpersonal relationships with others or to satisfy a self-interest arising from their children participation in sport if there is time to be able to do so (Sport England 2003, DCMS 2011). 
These results, consequently, imply that despite the general applicability of the established framework by which satisfaction, motivations, sports engagement and socio-economic circumstances affect volunteer behaviour, and can be employed to examine the transfer of effort across contexts, considerable nuance exists depending on that context. Indeed further variation in the results also provides support for the further hypothesis noted above, in which it is argued that the general drives to volunteer, for example stemming from altruism and selfinterest, might mean that a volunteer is prepared to transfer their efforts to another context, even if the current experience has not been satisfactory.

In this regard, the communication factor, as one of the satisfaction variables, actually records a lack of communication and organisation in the club and yet it is shown to have a positive effect on either rugby world cup volunteering, or intentions to volunteer at other rugby events, or other sports events but not future club volunteering. This means that there are 'push' factors to volunteering in other contexts that arise from unsatisfactory club volunteering, which implies some substitution of effort to a different context rather than the building of a complementary set of interests and community.

\section{Conclusions}

This article is one of the few studies, which has examined the linkage between sports club volunteering and volunteering in other contexts. It has also sought to address the limitations of past research (see Doherty 2009) by embracing all of the dimensions that are perceived to be relevant to understanding volunteer behaviour; that is, satisfaction, motivations, sports engagement and socio-economic characteristics, in this endeavour. The cases of actually volunteering for the rugby world cup, and intentions to volunteer for other rugby events, further club-rugby volunteering and volunteering at other sport events have been examined. There are limitations with the research, which are suggestive of future research activity. First, 
this is a study of one sport and clearly more work needs to be done investigating if the results transfer across other sporting contexts. Within the confines of the current study, and for future work, moreover, a greater sample size would improve the robustness of the findings. Longitudinal data would also be better in tracking the shifts of volunteering activity over time. Nonetheless, the main general findings of the research are that there is evidence in support of the relevance of the widely known determinants of volunteering to the continuation of future club volunteering as well as its transfer to rugby and other sport events.

This highlights the potential for sports governing bodies to recruit efforts from their existing volunteers in clubs to events organised by them, and that potential exists to transfer volunteer activity across to other sports contributing further to the Big Society agenda. Generally the research indicates that satisfied club volunteers have the potential to transfer effort to other contexts. It follows that communication of opportunities and the promotion of a rugby identity that is more collective than just the club, could harness this potential, if the benefits of developing a shared identity and how this could promote women's rugby further are communicated more clearly from the RFUW to its clubs and volunteers' network, as some VSCs seem reluctant to follow wider policy and NGB objectives, if by doing so there is no direct benefit to the club itself and its members (May et al. 2013).

However, the research also indicates that other, more tailored mechanisms might need to be developed. More specifically, the analysis broadly indicates that it is the uniqueness of the world cup that can be harnessed for club volunteers, but if the event is not to primarily recruit from current players and those with more flexibility in time and income, planning needs to be undertaken to develop more flexible timescales for involvement and, perhaps, to offer some support towards the costs of volunteering in other locations. Identifying the world-cup more clearly as being part of the continuum of a shared rugby experience, and perhaps in this 
regard less 'unique' by volunteers, might also be needed to help to recruit existing longerterm and more experienced club volunteers.

For recruitment to other rugby events, policy could emphasise the opportunity to make friends. However, it appears that such an opportunity rests on volunteers being retired. If this involves drawing upon existing and older club volunteers, who might also carry large club volunteering burdens, then clearly further coordination support might be offered by governing bodies to help to facilitate cross-club responsibilities.

From the point of view of generating further club volunteering, matters appear to be more complicated, as the analysis above suggested some satiation of activity, for example, once friends are made. This suggests that greater club memberships and the potential that this has for making new friends might need to be harnessed. However, the English sporting context is unique in its resistance to follow other European models of forming multi-sport hubs, where sport enthusiasts are brought together to share their love of sport, to cooperate and create opportunities of social mobility, which is then translated as an interest to various forms of sport participation (May et al. 2013). This could perhaps be addressed through regular local and regional multi-sport events or sport demonstration days organised by the volunteers in the area with the support of the NGBs. Governing bodies might seek to embrace wider communities than they have done before to support this. For example, this might take place in connection with other sports clubs, universities, schools and community groups. Lastly, in connection with volunteering in other sports, the results suggest that capitalising on younger to middle-aged volunteers might be appropriate. As noted above, this might be consistent with them having less club responsibilities and thus more time available to volunteer in other contexts (Sport England 2003, DCMS 2011). It remains, however, that across these contexts having an opportunity to have a satisfying experience and one within which altruistic 
objectives can be met should be a general policy emphasis for recruitment and retention of effort as well as its potential transfer.

This last objective is important because, uniquely, the current research indicates that a common determinant of either volunteering at the rugby world cup, or other rugby and sports events, is poor satisfaction with club experience. This suggests that some recruitment of volunteers to events can involve a substitution of effort as volunteers seek to satisfy their motives elsewhere. The challenge for policy is thus not to assume that all recruitment at such events is a success, but to ensure that such recruitment takes place in which it is fully viewed as a complementary activity, an aim towards which the policies described above might be targeted. Clearly this is an important area of future research.

The results of this article are relevant both to areas of recruitment and retention of sport volunteers. They also offer insights on how sport clubs’ volunteering can provide a platform for volunteer effort to be harnessed to other contexts, thus supporting the 'Big Society' policy. They also raise awareness on the challenges in implementing the 'Big Society' Policy in sports, as sport volunteering attracts a specific profile of individuals, which may deter potential volunteers from other ethnic backgrounds or with no existing social networks within sports to participate, suggesting that the decision to volunteer not only depends on government's agenda but more importantly on personal abilities, interests and the level of existing social capital (DCMS 2011).

\section{Disclosure statement}

No potential conflict of interest was reported by the authors 


\section{References}

Allison, M., 2001. Sport clubs in Scotland. Research Report 75, Sport Scotland: Edinburgh.

Bailey, S., Savage, S., and O’Connell, B., 2003. Volunteering and social capital in regional Victoria. Australian journal on volunteering, 8 (2), 5-12.

Bang, H. and Chelladurai, P., 2003. Motivation and satisfaction in volunteering for 2002 World Cup in Korea. Paper presented at the conference of the North American society for sport management. Ithaca, New York.

Bang, H., Alexandris, K., and Ross, S.D., 2008. Validation of the revised volunteer motivations scale for international sporting events (VMS-ISE) at the Athens 2004 Olympic Games. Event management, 12 (3), 119131.doi:10.3727/152599509789659759

Bourdieu, P., 1986. The forms of capital. In: J. Richards, ed. Handbook of theory and research for the sociology of education. New York: Greenwood Press, 241-258.

Burgham, M. and Downward, P., 2005. Why volunteer, time to volunteer? A case study from swimming. Managing leisure, 10 (2), 79-93.doi:10.1080/1360671050014610

Cabinet Office, 2010. Building the big society. [online]. Available from: http://www.cabinetoffice.gov.uk/sites/default/files/resources/building-big society_0.pdf. [Accessed 23 Sept 2014].

Clark, P.B. and Wilson, J.Q., 1961. Incentive systems: a theory of organizations. Administrative science quarterly, 6 (2), 129-166.doi:10.2307/2390752

Clary, E.G., et al., 1998. Understanding and assessing the motivations of volunteers: a functional approach. Journal of Personality and Social Psychology, 74 (6), 15161530.doi:10.1177/0021886391273003

Cnaan, R.A. and Goldberg-Glen, R.S., 1991. Measuring motivation to volunteer in human services. The journal of applied behavioral science, 27, 269284.doi:10.1177/0021886391273003

Coalter, F., 2007. A wider social role for sport. Who's keeping the score? London: Routledge.

Cohen, J., 1988. Statistical power for the behavioural sciences. $2^{\text {nd }}$ ed. Hillsdale, N.J.: Lawrence Erlbaum Associates.

Cuskelly, G., Hoye, R., and Auld, C., 2006. Working with volunteers in sport: Theory and practice. London, UK: Routledge, Taylor \& Francis Group.

Cuskelly G. and O'Brien, W., 2012. Changing roles: Applying continuity theory to understanding the transition from playing to volunteering in community sport. European sport management quarterly. doi:10.1080/16184742.2012.744767. 
DCMS/Strategy Unit, 2002. Game Plan: A strategy for delivering government's sport and physical activity objectives. London. DCMS.

DCMS, 2011. Taking part: The national survey of culture, leisure and sport. London. DCMS [online]. Available from: http://www.culture.gov.uk/publications/7995.aspx [Accessed 13 January 2015].

DCMS, 2012. Creating a sporting habit for life: a new youth sport strategy. London: DCMS.

Delaney, L. and Keaney, E., 2005. Cultural participation and social capital: Evidence from survey data. Dublin: Economic and Social Research Institute for public policy research, 32.

Doherty, A., 2009. The volunteer legacy of a major sport event. Journal of Policy Research in Tourism, Leisure, and Events, 1 (3), 185 -207. doi:10.1080/19407960903204356

Doherty, A., 2005. A profile of community sport volunteers. Ontario: Parks and Recreation Ontario and Sport Alliance of Ontario [online]. Available from: http://www.216.13.76.142/PROntario/PDF/reports/FinalReport_phaseOne2005.pdf [Accessed 16 Jan 2014].

Downward, P.M., Dejonghe, T., and Dawson, A., 2009. The Economics of sports: Theory, policy and evidence. Elsevier: London.

Downward, P. and Ralston, R., 2006. The sports development potential of sports event volunteering: insights from the XVII Manchester Commonwealth Games. European Sport Management Quarterly, 6, 333-351.doi:10.1080/16184740601154474

Downward, P. and Rasciute, S., 2012. Sport and social exclusion: an economic perspective. In: S. Dagkas \& K. Armour, eds. Inclusion and exclusion through youth sport. London: Routledge.

Dunning, E. and Sheard, K., 1979. Barbarians, gentlemen and players: a sociological study of the development of rugby football. Oxford: Martin Robertson.

Farrell, J.M., Johnston, M.E., and Twynam, G.D., 1998. Volunteer motivation, satisfaction and management at an elite sporting competition. Journal of sport management, 12, 288-300.

Frawley, S. and Cush, A., 2011. Major sport events and participation legacy: The case of the 2003 Rugby World Cup. Managing leisure, 16, 6576.doi:10.1080/13606719.2011.532605

Galindo-Kuhn, R. and Guzley, R.M., 2002. The volunteer satisfaction index: Construct definition, measurement, development, and validation. Journal of Social Service Research, 28 (1), 45-68. doi:10.1300/J079v28n01_03

Hair, J.F., et al., 2006. Multivariate data analysis. $6^{\text {th }}$ ed. Upper Saddle River, NJ: Pearson/Prentice Hall. 
Hallmann, K. and Harms, G., 2012. Determinants of volunteer motivation and their impact on future voluntary engagement: a comparison of volunteer's motivation at sport events in equestrian and handball. International journal of event and festival management, 3 (3), 272 - 291.doi:10.1108/17582951211262701

HM Government, 2010. Building a stronger civil society. London: Office for Civil Society, Cabinet Office.

Handy, F., and Brudney, J., 2007. When to use volunteer labour resource? an organizational analysis for nonprofit management. University of Pennsylvania Departmental Papers (SSP), Available from http://repository.upenn.edu/spp_papers/91/ [Assessed 18 March 2014].

Houlihan, B. and White, A., 2002. The politics of sport development: development of sport or development through sport? London: Routledge.

Hustinx, L., et al., 2010. Social and cultural origins of motivations to volunteer: a comparison of university students in six countries. International sociology, 25, 349-382. doi:10.1177/0268580909360297

Kisby, B., 2010. The Big Society: power to the people? The political quarterly, 81 (4), 484491.doi:10.1111/j.1467-923X.2010.02133.x

May, T., Harris, S. and Collins, M., 2013. Implementing community sport policy: understanding the variety of voluntary club types and their attitudes to policy. International journal of sport policy and politics, 5 (3), 397-419. doi:10.1080/19406940.2012.735688

McCabe, A., 2010. Below the radar in a big society? Reflections on community engagement, empowerment and social action in a changing policy context. Birmingham: TSRC Working Paper (51) [online]. Available from: http://www.tsrc.ac.uk/LinkClick.aspx?fileticket=OMbpEZaAMKI\%3d\&tabid=500. [Accessed 10 Sept 2014].

McClelland, D. C., 1961. The achieving society. New York: The Free Press

Morgan, H., 2013. Sport volunteering, active citizenship and social capital enhancement: what role in the 'Big Society'? International journal of sport policy and politics, 5 (3), 381-395. doi:10.1080/19406940.2013.764542

Nichols, G., 2006. Research into sports volunteers: reviewing the questions.Voluntary Action:The Journal of the Institute for Volunteering Research, 8 (1), 55-65.

Nichols, G. and Padmore, J., 2005. Who are the volunteers in sports clubs? Sheffield University Management School, working paper.

Nicholson, M. and Hoye, R., 2008. Sport and social capital. In: M. Nicholson \& R. Hoye, eds. Sport and social capital. London: Elsevier, Butterworth Heinemann, 1-18.

Oliver, R.L., 1980. A cognitive model of the antecedents and consequences of satisfaction decisions. Journal of marketing research, 17, 460-469. doi:10.2307/3150499 
Pattie, C. and Johnston, R., 2011. How big is the Big Society? Parliamentary affairs, 64, (3), 403-424. doi:10.1093/pa/gsr013

Paylor, K., 2011. Volunteering and health: Evidence of impact and implications for policy and practice. Institute for Volunteering Research [online]. Available from: http://www.ivr.org.uk/Institute+of+Volunteering+Research\%2fDoH+literature+revie w+October+2011.pdf [Accessed 23 Jan 2014].

Putnam, D., 2000. Bowling alone: The collapse and revival of American community. New York: Simon Schuster.

Ramchandani, G.M. and Coleman, R.J., 2012. The inspirational effects of three major sport events. International journal of event and festival nanagement, 3 (3), 257 - 271. doi:10.1108/17582951211262693

RFUW, 2010. Community development through rugby. Rugby development in the community. Report to the Department of Culture, Media and Sport. Twickenham: Rugby Football Union [online]. Available from: http://www.rfu.com/WomensRugbyPortal [Accessed 23 Oct 2010].

Schlesinger, T., Egli, B., and Nagel, S., 2012. Continue or terminate? Determinants of longterm volunteering in sports clubs. European sport management quarterly. doi:10.1080/16184742.2012.744766

Schulz, J., Nichols, G., and Auld, C.J., 2010. Issues in the management of voluntary sport organisations and volunteers. In: B.Houlihan and M.Green, eds, The Routledge Handbook of Sports Development, London: Routledge.

Scott, M., 2011. Reflections on the Big Society. Community Development Journal, 46 (1), 132-137. doi:10.1093/cdj/bsq057

Silverberg, K.E., Marshall, E.K., and Ellis, G.D. 2001. Measuring job satisfaction of volunteers in public parks and recreation. J Park Recreat Adm, 19 (1), 79-92.

Slaughter, L., 2002. Motivations of long term volunteers at events. Journal of Sport \& Tourism, 7 (3), 35-36. doi:10.1080/10295390208718732

Smith, M.J., 2010. From 'Big Government' to 'Big Society': changing the state-society balance. Parliamentary affairs, 63 (4), 818-833. doi:10.1093/pa/gsq023

Solberg, H.A. and Preuss, H., 2007. Major sport events and long- term tourism impacts. Journal of Sport Management, 21, 213-234. Human Kinetics.

Sport England, 2003. Sports volunteering in England in 2002: Summary report of the findings of the sports volunteering study commissioned by Sport England. London: Sport England [online]. Available from: http://www.sportengland.org/volunteering-inengland.pdf [Accessed 13 July 2013]. 
Sport England, 2009. Active People Survey 1 [online]. Available from: http://www.sportengland.org/research/active_people_survey/active_people_survey_1. aspx[Accessed 18 May 2015].

Stebbins, R.A., 1996. Volunteering: a serious leisure perspective. Nonprofit and voluntary sector quarterly, 25, 211-224. doi:10.1177/0899764096252005

Stevens. J., 1996. Applied multivariate statistics for the social sciences. $3^{\text {rd }}$ ed. Mahwah, NJ: Lawrence Erlbaum Associates.

Strigas, A. D., and Newton Jackson, E.Jr., 2003. Motivating volunteers to serve and succeed: design and results of a pilot study that explores demographics and motivational factors in sport volunteerism. International Sports Journal 7 (1) 111.

Suhr, D. and Shay, M., 2009. Guidelines for reliability, confirmatory and exploratory factor analysis [online]. Available from: http://www.wuss.org/proceedings09/09WUSSProceedings/papers/anl/ANLSuhrShay.pdf. [Accessed 15 Mar 2014].

Taylor, P., 2004. Driving up participation: The challenge for sport. London: Sport England.

Taylor, P. D., Panagouleas, T., and Nichols, G., 2012. Determinants of sports volunteering and sports volunteer time in England. International journal of sport policy and politics, 4 (2), 201-220. doi:10.1080/19406940.2012.656679

Table 1: Dependent Variables

\begin{tabular}{cccc}
\hline Variable Name & Description & Mean & Standard Deviation \\
\hline rwc & $\begin{array}{c}\text { Volunteered at the Rugby } \\
\text { World Cup or not }\end{array}$ & 0.235 & 0.426 \\
othrugevt & $\begin{array}{c}\text { I am willing to volunteer for } \\
\text { any other rugby-related event }\end{array}$ & 5.298 & 1.573 \\
rugbyclbvol & $\begin{array}{c}\text { I intend to continue } \\
\text { volunteering at my rugby club } \\
\text { othspevt }\end{array}$ & $\begin{array}{c}\text { I am willing to volunteer for } \\
\text { any major sport event }\end{array}$ & 4.894 \\
\hline $\mathrm{n}=161$ & & & 1.708 \\
\hline
\end{tabular}


Table 2: Socio-demographic variables

\begin{tabular}{cccc}
\hline Variable & Description & Mean & St. Dev \\
\hline Gender & '1 Male, 0 Female' & 0.497 & 0.502 \\
Children & Have children '1 Yes, 0 No' & 0.267 & 0.444 \\
Ethnicity & '1 White British, 0 Other ethnicity' & 0.919 & 0.273 \\
Education & '1 Degree level education, 0 Other' & 0.621 & 0.468 \\
Fulltime & '1 Full time work, 0 Not' & 0.795 & 0.405 \\
Part time & '1 Part time work, 0 Not' & 0.087 & 0.283 \\
Student & '1 Student, 0 Not' & 0.031 & 0.174 \\
Retired* & '1 Retired, 0 Not' & 0.050 & 0.218 \\
age1824 & '1 Aged 18 to 24 years, 0 Not' & 0.149 & 0.357 \\
age2534 & '1 Aged 25 to 34 years, 0 Not’ & 0.267 & 0.444 \\
age3544 & '1 Aged 35 to 44 years, 0 Not' & 0.224 & 0.418 \\
age4559 & '1 Aged 45 to 59 years, 0 Not’ & 0.248 & 0.433 \\
age6069** & '1 Aged 60 to 69 years, 0 Not’ & 0.112 & 0.316 \\
\hline
\end{tabular}

Note: *Unemployed is omitted category

**Aged 70 years and above is omitted category

Table 3: Sports engagement and motivation variables

\begin{tabular}{ccccc}
$\begin{array}{c}\text { Variable } \\
\text { Name }\end{array}$ & n & Description & Mean & St.Dev \\
\hline $\begin{array}{c}\text { Engagement } \\
\text { plyrugby }\end{array}$ & 161 & Playing rugby '1 Yes, 0 No' & 0.590 & 0.493 \\
plyothsp & 161 & Playing other sport '1 Yes, 0 No' & 0.441 & 0.498 \\
type & 161 & Volunteer in women's game '1 Yes, 0 No' & 0.666 & 0.474 \\
years & 161 & Years volunteering at the club & 7.373 & 7.328 \\
hrsseason & 161 & Weekly hours volunteering in season & 8.689 & 10.150 \\
hrsnotseason & 161 & Weekly hours volunteering out of season & 6.515 & 9.720
\end{tabular}




\begin{tabular}{ccccc}
$\begin{array}{c}\text { othvol } \\
\text { Motivation }\end{array}$ & 161 & $\begin{array}{c}\text { Volunteer elsewhere ' 1 Yes, 0 No' } \\
\text { Range: '5 very important to 1 unimportant' }\end{array}$ & 0.317 & 0.466 \\
myneeds & 159 & Meets my needs or interests & 4.119 & 0.970 \\
othneeds & 159 & Meets needs of friends, family etc & 3.673 & 1.145 \\
paidwork & 159 & Connected to paid work & 1.937 & 1.071 \\
community & 158 & A need in the community & 3.594 & 1.047 \\
help & 160 & I wanted to help people & 4.206 & 0.728 \\
friends & 159 & Wanted to make friends & 3.459 & 0.946 \\
asked & 160 & I was asked for help & 3.531 & 1.046 \\
hadtime & 160 & Had time to spare & 3.081 & 1.040 \\
offered & 159 & I offered to help & 3.535 & 1.095 \\
clubstart & 156 & I started the club & 2.231 & 1.304 \\
goodatit & 158 & I am good at it & 3.652 & 0.944 \\
\hline
\end{tabular}




\begin{tabular}{|c|c|c|c|}
\hline Item & $\mathbf{n}$ & Mean & St.Dev \\
\hline I have gained some useful experience through volunteering in rugby & 168 & 6.02 & 1.199 \\
\hline I have the feeling that I am doing something stimulating & 168 & 5.87 & 1.128 \\
\hline Satisfied from giving something back to my club & 168 & 6.21 & 1.014 \\
\hline Satisfied from putting something back into the community with volunteering & 168 & 5.9 & 1.139 \\
\hline Satisfied from helping others through volunteering in rugby & 168 & 6.04 & 0.99 \\
\hline Satisfied from helping my club to function successfully & 167 & 6.14 & 1.049 \\
\hline Satisfied from the opportunity to gain new skills through volunteering & 168 & 5.37 & 1.429 \\
\hline Satisfied from the sense of belonging to the club and the community I have gained & 167 & 5.78 & 1.262 \\
\hline Satisfied from the social benefits I gain from volunteering in rugby clubs & 166 & 5.97 & 1.157 \\
\hline Satisfied from my volunteer role & 168 & 5.63 & 1.265 \\
\hline Satisfied with my abilities to cope with my volunteer tasks & 167 & 5.92 & 1.092 \\
\hline I find my volunteering experience in rugby worthwhile & 167 & 5.93 & 1.175 \\
\hline My club doesn't take its volunteers for granted & 167 & 4.87 & 1.606 \\
\hline My club carefully plans my volunteer workload & 167 & 3.89 & 1.552 \\
\hline I feel satisfied with the training and support I receive from my club & 167 & 4.46 & 1.597 \\
\hline I am satisfied with the interest shown by my club & 164 & 4.42 & 1.401 \\
\hline I feel I receive a fair amount of the recognition for the volunteer work I do & 166 & 4.8 & 1.453 \\
\hline When I do a good job in volunteering I receive the recognition for it that I should & 166 & 4.58 & 1.461 \\
\hline I do not feel that the volunteer work I do is appreciated & 167 & 3.53 & 1.689 \\
\hline There are few rewards for volunteers & 164 & 4.17 & 1.653 \\
\hline My efforts are rewarded the way they should be & 164 & 4.45 & 1.479 \\
\hline My club shows too little interest in the feelings of volunteers & 167 & 3.43 & 1.565 \\
\hline Many of the rules and procedures from the RFUW make doing a good job difficult & 157 & 3.99 & 1.41 \\
\hline I like doing the things I do during my volunteer experience & 166 & 5.58 & 1.171 \\
\hline I feel a sense of pride as a volunteer with my rugby club & 165 & 5.78 & 1.174 \\
\hline Communications seem good within my club & 168 & 4.91 & 1.443 \\
\hline The goals of my club are not clear to me & 167 & 3.38 & 1.555 \\
\hline I often feel that I do not know what is going on at my club & 166 & 3.18 & 1.562 \\
\hline My volunteer assignments are not fully explained & 168 & 3.18 & 1.454 \\
\hline
\end{tabular}




\section{Satisfaction Item}

I have gained some useful experience through volunteering in rugby

rolesatis

0.781

0.827

0.696

0.653

0.825

0.787

0.741

0.74

0.82

0.759

0.691

0.809

0.651

0.71

I feel I receive a fair amount of the recognition for the volunteer work I do

When I do a good job in terms of volunteering I receive the recognition for it that I should

My efforts are rewarded the way they should be

My club shows too little interest in the feelings of volunteers

0.773

The goals of my club are not clear to me

0.865

0.898

I often feel that I do not know what is going on at my club

0.72

My club doesn't take its volunteers for granted

My club carefully plans and schedules my volunteer workload

atisfied with the interest shown by my club

Many of the rules and procedures from the RFUW make doing a good job difficult

$0.844 \quad 0.66$


Eigenvalues after Rotation

Total Variance After Rotation (\%)

$n=141$
$8.472 \quad 3.423$

$29.214 \quad 11.803$

2.697

9.301 
Table 6: Regression Analyses

\begin{tabular}{|c|c|c|c|c|c|}
\hline & rWC & $\begin{array}{c}\text { Marginal } \\
\text { Effect }\end{array}$ & othrugevt & rugbyclbvol & othspevt \\
\hline rolesatisf & $\begin{array}{c}0.738^{* *} \\
(2.09)\end{array}$ & 0.348 & $\begin{array}{l}0.217 \\
(1.26)\end{array}$ & $\begin{array}{c}0.442^{* * *} \\
(3.56)\end{array}$ & $\begin{array}{c}0.336^{* *} \\
(2.18)\end{array}$ \\
\hline rewards1 & $\begin{array}{l}-0.512 \\
(-1.36)\end{array}$ & & $\begin{array}{c}-0.0297 \\
(-0.22)\end{array}$ & $\begin{array}{c}0.195 \\
(1.52)\end{array}$ & $\begin{array}{l}-0.205 \\
(-1.32)\end{array}$ \\
\hline communication & $\begin{array}{c}1.870^{* * *} \\
(4.18)\end{array}$ & 0.088 & $\begin{array}{c}0.390 * * * \\
(2.69)\end{array}$ & $\begin{array}{c}-0.0621 \\
(-0.53)\end{array}$ & $\begin{array}{c}0.287^{*} \\
(1.64)\end{array}$ \\
\hline support & $\begin{array}{c}0.811^{*} \\
(1.84)\end{array}$ & 0.038 & $\begin{array}{c}-0.0505 \\
(-0.31)\end{array}$ & $\begin{array}{c}-0.0431 \\
(-0.37)\end{array}$ & $\begin{array}{l}0.295 \\
(1.57)\end{array}$ \\
\hline rewards2 & $\begin{array}{l}-0.450 \\
(-1.12)\end{array}$ & & $\begin{array}{l}-0.127 \\
(-1.12)\end{array}$ & $\begin{array}{c}-0.0750 \\
(-0.70)\end{array}$ & $\begin{array}{c}0.0134 \\
(0.10)\end{array}$ \\
\hline plyrugby & $\begin{array}{c}2.235^{*} \\
(1.79)\end{array}$ & 0.099 & $\begin{array}{l}0.172 \\
(0.40)\end{array}$ & $\begin{array}{c}0.00711 \\
(0.02)\end{array}$ & $\begin{array}{l}0.189 \\
(0.42)\end{array}$ \\
\hline plyothsp & $\begin{array}{l}-0.854 \\
(-1.05)\end{array}$ & & $\begin{array}{l}-0.344 \\
(-0.95)\end{array}$ & $\begin{array}{l}0.210 \\
(0.79)\end{array}$ & $\begin{array}{c}0.0648 \\
(0.18)\end{array}$ \\
\hline type & $\begin{array}{l}-0.640 \\
(-0.63)\end{array}$ & & $\begin{array}{l}-0.485 \\
(-1.26)\end{array}$ & $\begin{array}{l}-0.223 \\
(-1.00)\end{array}$ & $\begin{array}{c}-0.0873 \\
(-0.21)\end{array}$ \\
\hline years & $\begin{array}{c}-0.121^{*} \\
(-1.71)\end{array}$ & -0.006 & $\begin{array}{c}0.00107 \\
(0.04)\end{array}$ & $\begin{array}{c}0.0170 \\
(0.93)\end{array}$ & $\begin{array}{c}0.0187 \\
(0.70)\end{array}$ \\
\hline hrsseason & $\begin{array}{l}0.239 \\
(1.45)\end{array}$ & & $\begin{array}{c}0.00157 \\
(0.03)\end{array}$ & $\begin{array}{c}-0.0262 \\
(-0.68)\end{array}$ & $\begin{array}{c}-0.0220 \\
(-0.36)\end{array}$ \\
\hline hrsnotseason & $\begin{array}{l}-0.220 \\
(-1.41)\end{array}$ & & $\begin{array}{c}0.0108 \\
(0.20)\end{array}$ & $\begin{array}{c}0.0291 \\
(0.68)\end{array}$ & $\begin{array}{c}0.0171 \\
(0.23)\end{array}$ \\
\hline othvol & $\begin{array}{l}1.016 \\
(1.29)\end{array}$ & & $\begin{array}{l}0.128 \\
(0.31)\end{array}$ & $\begin{array}{l}-0.437 \\
(-1.52)\end{array}$ & $\begin{array}{l}0.582 \\
(1.33)\end{array}$ \\
\hline myneeds & $\begin{array}{l}-0.620 \\
(-1.60)\end{array}$ & & $\begin{array}{l}-0.104 \\
(-0.54)\end{array}$ & $\begin{array}{c}-0.163 * \\
(-1.73)\end{array}$ & $\begin{array}{c}0.0689 \\
(0.34)\end{array}$ \\
\hline othneeds & $\begin{array}{c}1.345^{* * *} \\
(2.57)\end{array}$ & 0.063 & $\begin{array}{c}-0.253^{*} \\
(-1.77)\end{array}$ & $\begin{array}{c}0.0546 \\
(0.58)\end{array}$ & $\begin{array}{c}-0.353^{* *} \\
(-2.48)\end{array}$ \\
\hline paidwork & $\begin{array}{l}0.617 \\
(1.39)\end{array}$ & & $\begin{array}{l}-0.166 \\
(-1.11)\end{array}$ & $\begin{array}{c}0.0516 \\
(0.42)\end{array}$ & $\begin{array}{c}-0.0836 \\
(-0.50)\end{array}$ \\
\hline community & $\begin{array}{l}-0.300 \\
(-0.66)\end{array}$ & & $\begin{array}{l}0.188 \\
(1.16)\end{array}$ & $\begin{array}{c}0.00298 \\
(0.02)\end{array}$ & $\begin{array}{c}0.0899 \\
(0.54)\end{array}$ \\
\hline help & $\begin{array}{l}0.916 \\
(1.59)\end{array}$ & & $\begin{array}{c}0.0509 \\
(0.22)\end{array}$ & $\begin{array}{c}-0.395^{* *} \\
(-2.15)\end{array}$ & $\begin{array}{c}0.380^{*} \\
(1.85)\end{array}$ \\
\hline friends & $\begin{array}{l}0.158 \\
(0.22)\end{array}$ & & $\begin{array}{c}0.496^{* *} \\
(2.17)\end{array}$ & $\begin{array}{c}0.334 * * \\
(2.24)\end{array}$ & $\begin{array}{l}0.245 \\
(1.02)\end{array}$ \\
\hline asked & $\begin{array}{l}-0.407 \\
(-0.80)\end{array}$ & & $\begin{array}{c}0.0730 \\
(0.54)\end{array}$ & $\begin{array}{l}-0.100 \\
(-1.13)\end{array}$ & $\begin{array}{l}0.107 \\
(0.65)\end{array}$ \\
\hline hadtime & $\begin{array}{c}1.210 * * \\
(2.18)\end{array}$ & 0.057 & $\begin{array}{l}-0.283 \\
(-1.84)\end{array}$ & $\begin{array}{l}0.191 \\
(1.63)\end{array}$ & $\begin{array}{c}0.00375 \\
(0.02)\end{array}$ \\
\hline offered & $\begin{array}{r}0.282 \\
(0.74)\end{array}$ & & $\begin{array}{c}0.344 * * \\
(2.35)\end{array}$ & $\begin{array}{l}0.121 \\
(1.25)\end{array}$ & $\begin{array}{l}0.126 \\
(0.76)\end{array}$ \\
\hline clubstart & $\begin{array}{l}-0.374 \\
(-1.27)\end{array}$ & & $\begin{array}{c}-0.0885 \\
(-0.68)\end{array}$ & $\begin{array}{l}-0.118 \\
(-1.10)\end{array}$ & $\begin{array}{c}-0.0691 \\
(-0.48)\end{array}$ \\
\hline goodatit & 0.673 & & -0.0843 & 0.0910 & -0.239 \\
\hline
\end{tabular}




\begin{tabular}{|c|c|c|c|c|c|}
\hline & (1.17) & & $(-0.46)$ & $(0.46)$ & $(-1.16)$ \\
\hline \multirow[t]{2}{*}{ gender } & 0.725 & & 0.540 & 0.226 & 0.626 \\
\hline & $(0.64)$ & & (1.43) & (0.93) & $(1.44)$ \\
\hline \multirow[t]{2}{*}{ children } & -0.660 & & -0.0680 & 0.508 & 0.0220 \\
\hline & $(-0.57)$ & & $(-0.17)$ & (1.63) & $(0.05)$ \\
\hline \multirow[t]{2}{*}{ ethnicity } & $7.245 * * *$ & 0.079 & $1.135^{* *}$ & $1.741 * * *$ & $1.470 * * *$ \\
\hline & $(2.56)$ & & $(2.32)$ & (3.98) & (2.99) \\
\hline \multirow[t]{2}{*}{ education } & $2.699 * * *$ & 0.118 & -0.516 & 0.0486 & -0.418 \\
\hline & (2.64) & & $(-1.62)$ & $(0.18)$ & $(-1.15)$ \\
\hline \multirow[t]{2}{*}{ Fulltime } & $-4.950^{* *}$ & -0.708 & 0.734 & -0.311 & 0.226 \\
\hline & $(-2.01)$ & & $(0.92)$ & $(-0.46)$ & $(0.31)$ \\
\hline \multirow[t]{2}{*}{ Parttime } & -2.958 & & 1.468 & -0.346 & 0.772 \\
\hline & $(-1.14)$ & & (1.56) & $(-0.44)$ & $(0.86)$ \\
\hline \multirow[t]{2}{*}{ Student } & $-6.857 *$ & -0.058 & 1.034 & 0.715 & 0.0992 \\
\hline & $(-1.78)$ & & (1.06) & $(0.86)$ & $(0.11)$ \\
\hline \multirow[t]{2}{*}{ Retired } & 1.924 & & $2.116^{* *}$ & 0.720 & 0.878 \\
\hline & $(0.94)$ & & (2.38) & (1.15) & $(0.92)$ \\
\hline \multirow[t]{2}{*}{ age1824 } & 0.590 & & 1.096 & 0.689 & $2.694 * * *$ \\
\hline & $(0.29)$ & & (1.45) & (0.99) & (3.27) \\
\hline \multirow[t]{2}{*}{ age2534 } & -2.603 & & 1.153 & 0.703 & $1.789 * *$ \\
\hline & $(-1.21)$ & & $(1.42)$ & (1.08) & $(2.25)$ \\
\hline \multirow[t]{2}{*}{ age3544 } & -1.162 & & 0.594 & -0.0599 & $1.708 * *$ \\
\hline & $(-0.55)$ & & $(0.81)$ & $(-0.09)$ & $(2.11)$ \\
\hline \multirow[t]{2}{*}{ age4559 } & -0.176 & & 0.364 & 0.716 & 1.003 \\
\hline & $(-0.11)$ & & $(0.57)$ & $(1.40)$ & $(1.57)$ \\
\hline \multirow[t]{2}{*}{ _cons } & $-18.82^{* *}$ & & 1.998 & $4.061^{* * *}$ & -0.198 \\
\hline & $(-3.10)$ & & (1.38) & $(4.01)$ & $(-0.14)$ \\
\hline $\mathrm{n}$ & 131 & & 131 & 131 & 131 \\
\hline $\mathrm{R}^{2}$ & & & 0.367 & 0.446 & 0.394 \\
\hline Pseudo $\mathrm{R}^{2}$ & 0.551 & & & & \\
\hline Wald $\chi^{2}(35)$ & $49.83 * *$ & & & & \\
\hline$F(35,95)$ & & & $3.11^{* *}$ & $4.63 * * *$ & $4.91 * * *$ \\
\hline
\end{tabular}

Note: $t$ statistics in parentheses

${ }^{*} p<0.1,{ }^{* *} p<0.05,{ }^{* * *} p<0.01$ 